\title{
SIMULATED ATTACK OF DEFOLIATING INSECTS ON UPLAND RICE CULTIVATED IN NEW AGRICULTURAL FRONTIER FROM AMAZON RAINFOREST REGION (BRAZIL) AND ITS EFFECT ON GRAIN PRODUCTION
}

\author{
ATAQUE SIMULADO DE INSETOS DESFOLHADORES EM ARROZ DE TERRAS \\ ALTAS CUTIVADO NA NOVA FRONTEIRA AGRÍCOLA DA FLORESTA \\ AMAZÔNICA (BRASIL) E SEU EFEITO SOBRE A PRODUÇÃO DE GRÃOS
}

\author{
Diones KRINSKI ${ }^{1}$; Luís Amilton FOERSTER ${ }^{2}$ \\ 1. Professor, Doutor, Departamento de Ciências Biológicas, Universidade do Estado de Mato Grosso, Campus Universitário de Tangará \\ da Serra - UNEMAT/CUTS, Tangará da Serra, MT, Brazil. dioneskrinski@ gmail.com; 2. Professor, Doutor, Departamento de \\ Zoologia, Universidade Federal do Paraná - UFPR, Curitiba, PR, Brazil.
}

\begin{abstract}
Simulation of the attack of defoliating insects provides a measurement of the level of damage that the crop can support at a given developmental stage and also allows to quantify the loss of productivity. This study evaluated the effects of increasing levels of artificial defoliation in upland rice plants under field conditions, on grain production at three phenological stages, vegetative stage V8 (collar formation in the 8th leaf of the main stem), vegetative stage V12 (formation of the flag leaf) and reproductive stage R3/R4 (liberation of the panicle or anthesis). The percentage of damage at all stages increased significantly from $25 \%$ defoliation, and was higher when defoliation occurred in V8 and V12. Defoliation levels up to $50 \%$ in the reproductive stage did not influence the quantity of filled grains, total spikelets per panicle and weight of filled grains per panicle, and thus the pest control is not required at this stage. The data show that the control of leaf-chewing insects in upland rice should be restricted to the vegetative stage.
\end{abstract}

KEYWORDS: Integrated pest management. Leaf area reduction. Rice crop.

\section{INTRODUCTION}

Rice (Oryza sativa L.) is one of the most ancient cultivated plant species and currently occupies $10 \%$ of the agricultural lands of the planet (CHANG, 2003). Because it is a staple food for more than $1 / 3$ of the world population, rice is considered one of the most economically important grains in the world (COATS, 2003). Currently, the annual worldwide rice production is approximately 741 million tons, being Asia the main producer with over $90 \%$ of the rice grown. In the last 13 years Brazil stands out for being the only non-Asian country among the nine largest producers with about $1.64 \%$ of the world rice production $(12.175 .602 \mathrm{t})$ surpassing since 2003 even Japan (FAO, 2016).

However, even with the increase in rice production in Brazil, rice crops are often subjected to leaf area loss by defoliating insects of the orders Coleoptera, Orthoptera, Hymenoptera (Formicidae, Myrmicinae) and mainly Lepidoptera (DIDONET et al., 2001; MACHADO; GARCIA, 2010). The action of these insects is one of the main causes of reduction in productivity of rice crops, but some species receive more importance due to the economic losses they cause to the crops (PATHAK; KHAN, 1994; GOMES; MAGALHÃES-JUNIOR, 2004; MARTINS et al., 2004a). Lepidopterans can cause losses in productivity from sowing to harvest, with significant yield reductions of up to $35 \%$ in crops with application of pesticides (COSTA; LINK, 1999; COSTA et al., 2006; KRINSKI, 2015, KRINSKI; GODOY, 2015). In crops with no chemical control, depending on the population of noctuid caterpillars, such as Mocis latipes (Guenée, 1852), Spodoptera frugiperda (J.E. Smith, 1797), Spodoptera litura (Fabricius, 1775), Leucania humidicola (Guenée, 1852), Pseudaletia (=Mythimna, Leucania) adultera (Schaus, 1894), P. sequax (Flanclemont, 1951) and the crambid Chilo suppressalis (Walker, 1863), losses can reach 100\% (GRÜTZMACHER et al., 1999a, b; LOECK et al., 1999; MARTINS et al., 2004b; 2009; MARTINS; AFONSO, 2007; BARRIGOSSI, 2010; SHAD et al., 2012; YUAN et al., 2012).

The assessment of the effect of artificial defoliation on plants of economic importance, such as rice, is a useful methodology to simulate damage. Since it is possible to measure how much defoliation the crop can sustain in a given phenological stage, yield loss for the different levels of defoliation can be assessed (MOSCARDI; VILLAS-BÔAS, 1982; FAZOLIN; ESTRELA, 2003). In addition, this parameter can be used to estimate the economic injury level (EIL), similar to that conducted for soybean crops, where the number of pest insects and 
percentage of defoliation are used to indicate the moment when chemical control is required (HOFFMANN-CAMPO et al., 2000; BUENO et al., 2012).

Therefore, in this study increasing levels of artificial defoliation was simulated at different phenological stages of upland rice to estimate the damage caused by defoliating insects on grain production. In addition, it was examined in which developmental phase the plants are more susceptible to defoliation.

\section{MATERIAL AND METHODS}

The study was carried out during the 2011/2012 rice crop in an upland rice field ( Cambará variety), at the Florentino Farm $\left(7^{\circ} 07^{\prime} 45.71^{\prime \prime} \mathrm{S} 55^{\circ} 23^{\prime} 21.13^{\prime \prime} \mathrm{W}\right)$, municipality of Novo Progresso, state of Pará (Amazon Rainforest region), Brazil. This cultivar was used by the farmer due to some characteristics, such as wide adaptability, plant architecture, midsize, resistance to lodging, a cycle of 105 days, good stay-green, high yield and entire and translucent grains. Also, it has good tolerance to leaf scald, leaf blotch complex and patches of grain. It can be planted in newly opened areas, renovation of pastures, old lands and crop rotation (FERREIRA; SANTIAGO, 2012). The experiment consisted of five levels of defoliation, $0 \%$ (control), $25 \%, 50 \%, 75 \%$, and $90 \%$, in three phenological stages of rice, two of them during the vegetative stage, V8 (formation of the collar in the 8th leaf of the main stem) and V12 (formation of the flag leaf) and one at the reproductive stage R3/R4 (release of panicle or anthesis), totaling 15 treatments (COUNCE et al., 2000). Parts of leaves were manually removed from all plants to the corresponding percentages of defoliation (Figure 1). For each treatment, 50 rice plants (replicates) from the same row in the field were randomly selected. To ensure that plants were not attacked by insects during the experiment, chemical control with Permethrin (Pounce ${ }^{\circledR} 384$ EC) was performed until harvest.

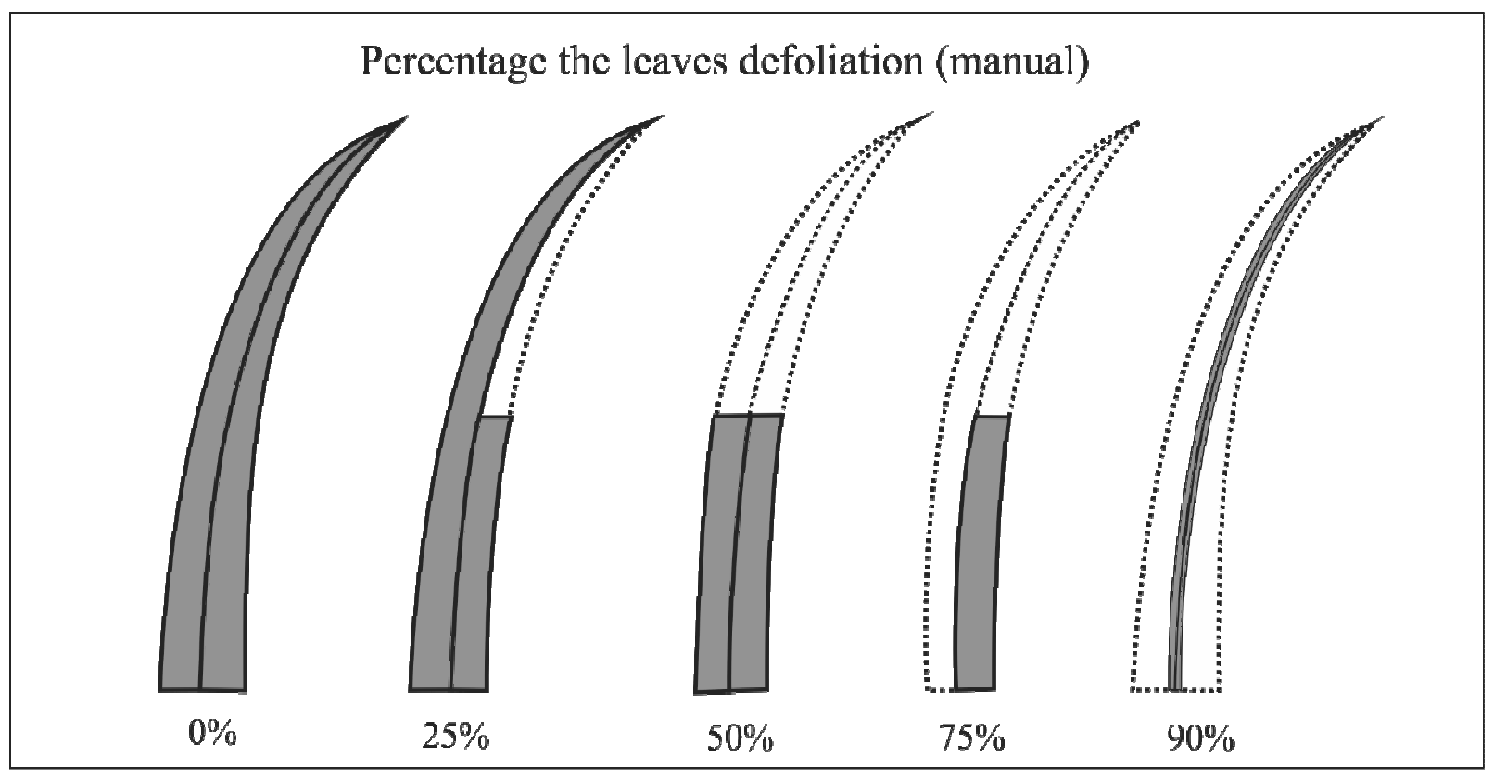

Figure 1. Percentage of defoliation used in the experiments.

The total production of spikelets per panicle was evaluated, as well as the number of filled and empty spikelets per panicle. The percentage of damage (reduction in grain production) for each level of defoliation in the different phenological stages (damage: ES/TS*100, where ES is the number of Empty Spikelets per panicle and TS is the Total number of Spikelets per panicle), average weight of filled grains per panicle (grain mass) and the average weight of 100 rice grains (total weight of filled grains/number of filled grains*100) also were evaluated. A completely randomized design with treatments in a factorial scheme $(3 \times 5)$ was used. We tested the interaction between two factors: phenological stages (x:1) and percentage of defoliation $(\mathrm{x}: 2)$. Normality was tested with the Shapiro-Wilk test with significance set at 5\%. Assuming a normal distribution, the results were compared with analysis of variance (ANOVA) and the means classified with Tukey's test at 5\%. When assumptions of normality were not met, the nonparametric Kruskal-Wallis test with significance set at $5 \%$ was used instead. When $\mathrm{F}$ or $\mathrm{H}$ were significant $(\mathrm{P}<0.05)$, a linear regression analysis was performed with the statistical software Assistat version 7.7 beta (SILVA; AZEVEDO, 2002). 


\section{RESULTS AND DISCUSSION}

Our findings support those by Watson (1952) that reported that leaf area is among the main factors affecting yield in several crops, and consequently determining dry matter production and final yield. According to Walter et al. (2012), the vegetative phase is the period when rice plants are most sensitive to photoperiod. Since dry matter production of rice is calculated based on the radiation use efficiency and the leaf area index, loss of leaf area in this stage can directly affect the intercepted solar radiation used for plant growth, and grain production. In this study, this occurred mainly when defoliation was carried out in the vegetative stage (Figure 2).

The average total number of spikelets (filled and empty) among the percentages of defoliation in
KRINSKI, D.; FOERSTER, L. A.

the different phenological stages ranged between $93.7 \pm 5.1$ and $183.5 \pm 4.5$ per panicle. The results for total spikelets showed significant difference for the isolated factors (phenological stage $-\mathrm{DF}=2 ; \mathrm{F}=$ 77.6750; $\mathrm{P}<0.001$ and percentage of defoliation $\mathrm{Df}=4, \mathrm{~F}=\mathrm{F}=46.0361 ; \mathrm{P}<0.001)$. Also, there was significant difference for interaction between the tested factors $(\mathrm{Df}=8 ; \mathrm{F}=11.6961 ; \mathrm{P}<0.001 ; \mathrm{C} . \mathrm{V} .=$ $26.75 \%$ ). In the vegetative stage, $25 \%$ or more defoliation caused a significant reduction in the total number of spikelets compared to the control group. When the damage occurred in the reproductive stage, only defoliation of $75 \%$ or more resulted in a significant reduction in the number of spikelets (about 25\% lower than control). Defoliation of up to $50 \%$ in this phenological phase did not reduce the total number of spikelets. (Figure 2A).

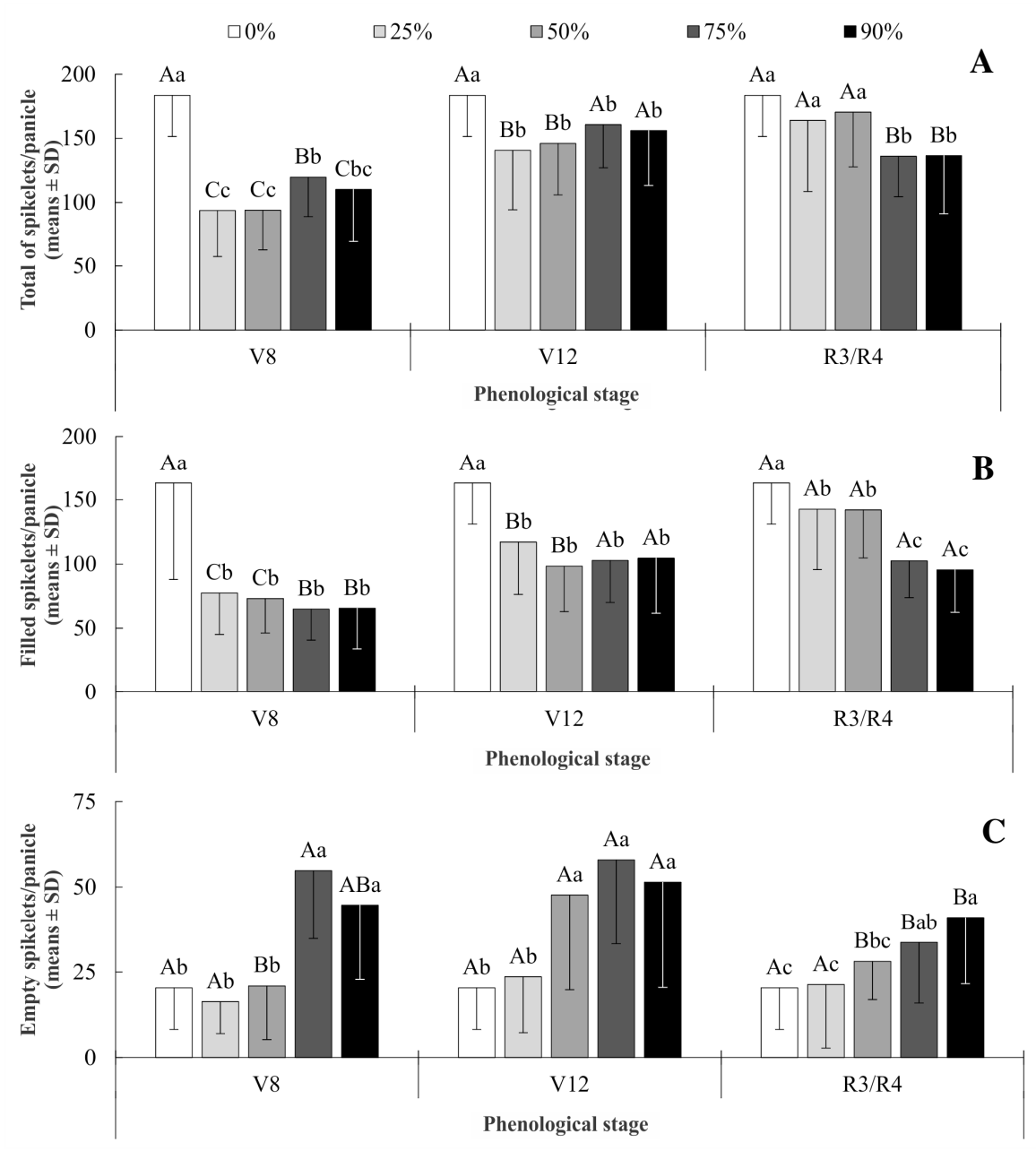

Figure 2. Mean number $( \pm S D)$ of total spikelets per panicle (A), filled grains per panicle (B) and empty spikelets per panicle (C) after different percentages of defoliation on upland rice plants at different growth stages. Novo Progresso - Pará State, Brazil. 2011-2012. Capital letters compares the values between growth stages (bars with the same color). Lowercase letters compare the values to different percentages of defoliation within the same developmental stage (different color bars). 
The average number of filled grains per panicle ranged between $64.9 \pm 3.4$ and $163.2 \pm 4.6$ among treatments. The results for filled grains showed significant difference for the isolated factors (phenological stage - $\mathrm{DF}=2 ; \mathrm{F}=90.3524 ; \mathrm{P}<0.001$ and percentage of defoliation - $\mathrm{Df}=4, \mathrm{~F}=\mathrm{F}=$ 116.7168; $\mathrm{P}<0.001)$ and for interaction between the tested factors $(\mathrm{Df}=8 ; \mathrm{F}=11.0113 ; \mathrm{P}<0.001 ; \mathrm{C} . \mathrm{V} .=$ $30.87 \%$ ). In the V8 stage, all percentages of defoliation resulted in reductions of over $50 \%$ in the number of filled grains per panicle in comparison with the control group. In V12 and R3/R4 stages, the results were similar, showing less pronounced differences. In all phenological stages the defoliation of $25 \%$ resulted in a significant reduction in filled grains compared to the control group, reducing more than 50, 30 and $10 \%$ the number of filled grains in V8, V12 and R3/R4 stages respectively (Figure 2B).

The number of empty spikelets per panicle increased along with defoliation percentage in the different phenological stages ranging between 16.3 \pm 1.3 and $58.0 \pm 3.5$. The results for empty spikelets showed significant difference for the isolated factors (phenological stage - DF= 2; F= 24.4042; $\mathrm{P}<0.001$ and percentage of defoliation $-\mathrm{Df}=4, \mathrm{~F}=75.6662$; $\mathrm{P}<0.001$ ), and also showed significant difference for interaction between the tested factors $(\mathrm{Df}=8 ; \mathrm{F}=$ 8.0431; $\mathrm{P}<0.001 ; \mathrm{C} . \mathrm{V} .=56.79 \%)$ (Figure 2C).

Defoliation of up to $75 \%$ resulted in significant differences in V8 stage and of up to $50 \%$ in the V12 and R3/R4 stages. In the V8 stage, plants withstood defoliation of up to $50 \%$ without increasing the number of empty spikelets when compared to the control group. The V12 stage had the largest number of empty spikelets per panicle for all percentages of defoliation. In the reproductive stage R3/R4, the results were different from those obtained in the vegetative stage, even with the increased number of empty spikelets observed in defoliations of 75 and 90\% (Figure 2C).

Walter et al. (2012) reported that senescence of leaves and stem begins with anthesis (reproductive phase), when part of the dry matter produced begins to be directed to the panicle, and grain filling initiates. Thus, any interference before anthesis is expected to have an effect on the final production, reflected as a decrease in the number of filled grains, increase in empty spikelets or the total number of spikelets per panicle (Figures 3abc).

The percentage of damage (ES/TS*100) caused by the different levels of defoliation ranged from $11.1 \pm 0.9 \%$ to $45.9 \pm 1.7 \%$ in the treatments and phenological stages examined. In all percentages of defoliation, damage was higher in the vegetative stage (Table 1). Within each phenological stage, the damage was higher in V8, with significant differences beginning with $25 \%$ defoliation. The same pattern was observed for the reproductive stage $\mathrm{R} 3 / \mathrm{R} 4$. In the $\mathrm{V} 12$ stage, the damage caused by defoliation of $25 \%$ was not significantly different from that of the control, but was three times higher than the control at 50\% defoliation (Table 1).

These results differ from those obtained in other studies reporting that rice plants can recover from initial damage without yield loss (SILVA, 1984). In the present study, most damage was caused by defoliation in the vegetative stage V8 (45.9\%), unlike the observed by Bowling (1978) that reported a decrease of approximately $12 \%$ for this same stage. This might be a peculiarity of the Cambará cultivar used in this study. As reported by Bowling (1978), different varieties or plants under stress conditions may respond differently to defoliation.

The decrease in average weight $(\mathrm{g})$ of filled grains per panicle in each phenological stage and the percentage of defoliation exhibited the same pattern found for the reduction in the quantity of filled grains per panicle. When defoliation was caused at $\mathrm{V} 8$, the percentage of weight reduction per panicle was $16.7 \%, 34.2 \%, 60.3 \%$, and $53.1 \%$ for defoliation of $25 \%, 50 \%, 75 \%$, and $90 \%$, respectively. Rice plants in V8 stage were able to recover from defoliation of $25 \%$ without yield reductions, while defoliation of over $50 \%$ in this stage significantly reduced the weight of filled grains per panicle. In the V12 stage, the values found were $33.17 \%, 38.40 \%, 36.91 \%$, and $42.89 \%$ with these same levels of defoliation, and the defoliation of over $25 \%$ in this stage significantly reduced the weight per panicle. In stage R3/R4 the decrease in grain mass with defoliation of $25 \%$, $50 \%, 75 \%$ and $90 \%$ were $9.5 \%, 8.2 \%, 36.7 \%$, and $41.2 \%$, respectively, and the differences in grain mass were only observed for defoliation of $75 \%$ and above. These results support the ones obtained by Martins et al. (1982) that reported that plants are not able to recover from the loss of leaves near the reproductive stage, thus affecting grain filling. In the R3/R4 stage, however, significant differences in weight of filled grains per panicle were observed only for defoliation of $75 \%$ and above (Table 1). Similar results for the reproductive phase were obtained by Martins et al. (1982) that reported a decrease in weight as a result of defoliation of over $75 \%$. 

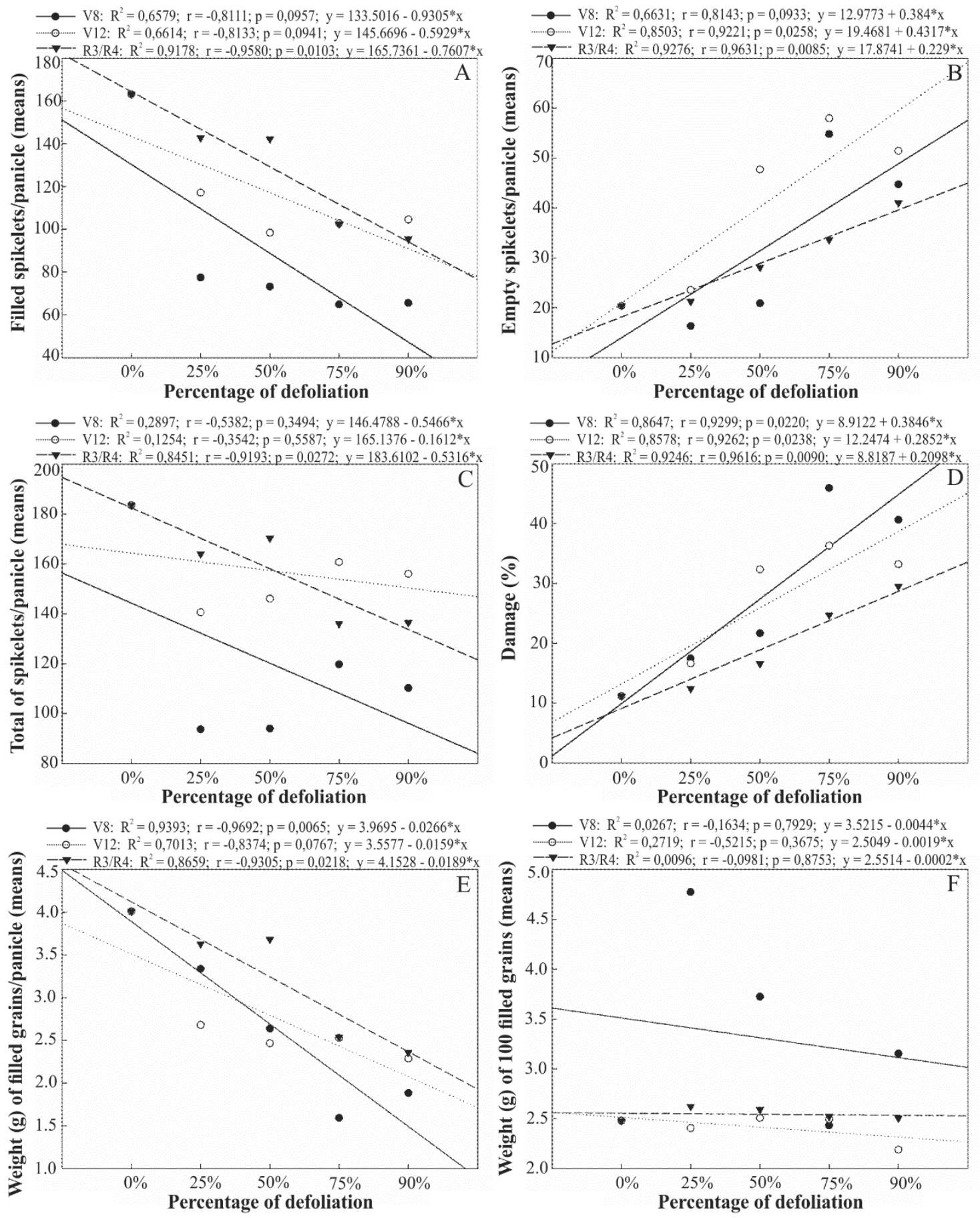

Figure 3. Linear regression (with $\mathrm{R}^{2}$ ): A) Number of filled grains per panicle; B) Number of empty spikelets per panicle; C) Total number of grains (empty and filled) per panicle; D) Percentage of damage; E) Weight of filled grains per panicle; and F) Weight of 100 grains of rice, in the different phenological stages and percentage of defoliation. 
Table 1. Percentage of damage (ES/TS*100), average weight (g) of filled grains per panicle and average weight $(\mathrm{g})$ of 100 filled per panicle caused by different levels of defoliation (\%) in three phenological stages from upland rice. Novo Progresso, PA, Brazil 2011-2012

\begin{tabular}{|c|c|c|c|c|c|c|c|c|}
\hline \multirow{2}{*}{\multicolumn{2}{|c|}{$\begin{array}{l}\text { Phenological } \\
\text { stages }\end{array}$}} & \multicolumn{5}{|c|}{ Percent defoliation $\left(\right.$ mean $\left.^{1} \pm \mathrm{SE}^{*}\right)$} & \multirow[b]{2}{*}{$\mathrm{H}^{2}$} & \multirow[b]{2}{*}{$P$} \\
\hline & & $0 \%$ & $25 \%$ & $50 \%$ & $75 \%$ & $90 \%$ & & \\
\hline \multirow{6}{*}{ 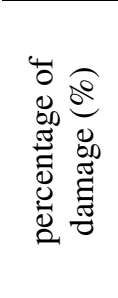 } & V8 & $11.1 \pm 0.9 \mathrm{C}$ & $17.4 \pm 1.1 \mathrm{aB}$ & $21.6 \pm 1.6 \mathrm{bB}$ & $45.9 \pm 1.7 \mathrm{aA}$ & $40.6 \pm 2.0 \mathrm{aA}$ & 163.235 & 0.000 \\
\hline & V12 & $11.1 \pm 0.9 \mathrm{~B}$ & $16.6 \pm 1.5 \mathrm{aB}$ & $32.6 \pm 2.3 \mathrm{aA}$ & $36.3 \pm 2.0 \mathrm{bA}$ & $33.2 \pm 2.5 \mathrm{bA}$ & 105.944 & 0.000 \\
\hline & $\mathrm{R} 3 / \mathrm{R} 4$ & $11.1 \pm 0.9 \mathrm{C}$ & $12.4 \pm 1.1 \mathrm{bB}$ & $16.5 \pm 0.7 \mathrm{bB}$ & $24.7 \pm 1.5 \mathrm{cA}$ & $29.5 \pm 1.4 \mathrm{bA}$ & 111.372 & 0.000 \\
\hline & $\mathrm{H}^{2}$ & - & 18.984 & 29.765 & - & 12.553 & & \\
\hline & $\mathrm{F}^{3}$ & - & - & - & 35.210 & - & & \\
\hline & $P$ & - & 0.0001 & 0.000 & 0.000 & 0.0019 & & \\
\hline \multirow{6}{*}{ 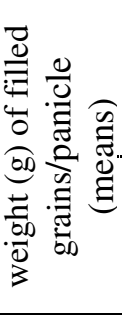 } & V8 & $4.0 \pm 0.1 \mathrm{~A}$ & $3.3 \pm 0.1 \mathrm{aA}$ & $2.6 \pm 0.1 \mathrm{bAB}$ & $1.5 \pm 0.1 \mathrm{bB}$ & $1.8 \pm 0.1 \mathrm{bB}$ & 137.814 & 0.000 \\
\hline & V12 & $4.0 \pm 0.1 \mathrm{~A}$ & $2.6 \pm 0.1 \mathrm{bB}$ & $2.4 \pm 0.1 \mathrm{bB}$ & $2.5 \pm 0.1 \mathrm{aB}$ & $2.2 \pm 0.1 \mathrm{abB}$ & 76.697 & 0.000 \\
\hline & $\mathrm{R} 3 / \mathrm{R} 4$ & $4.0 \pm 0.1 \mathrm{~A}$ & $3.6 \pm 0.1 \mathrm{aA}$ & $3.6 \pm 0.1 \mathrm{aA}$ & $2.5 \pm 0.1 \mathrm{aB}$ & $2.3 \pm 0.1 \mathrm{aB}$ & 97.386 & 0.000 \\
\hline & $\mathrm{H}^{2}$ & - & 20.615 & - & 45.607 & 8.0313 & & \\
\hline & $\mathrm{F}^{3}$ & - & - & 23.223 & - & - & & \\
\hline & $P$ & - & 0.000 & 0.000 & 0.000 & 0.018 & & \\
\hline \multirow{5}{*}{ 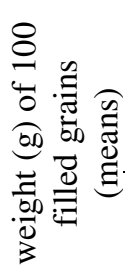 } & V8 & $2.4 \pm 0.0 \mathrm{C}$ & $4.7 \pm 0.2 \mathrm{aA}$ & $3.7 \pm 0.1 \mathrm{aA}$ & $2.4 \pm 0.0 \mathrm{abC}$ & $3.1 \pm 0.1 \mathrm{aB}$ & 114.936 & 0.000 \\
\hline & V12 & $2.4 \pm 0.0 \mathrm{~A}$ & $2.4 \pm 0.1 \mathrm{bA}$ & $2.5 \pm 0.0 \mathrm{cA}$ & $2.4 \pm 0.1 \mathrm{bA}$ & $2.2 \pm 0.1 \mathrm{bB}$ & 44.392 & 0.000 \\
\hline & $\mathrm{R} 3 / \mathrm{R} 4$ & $2.4 \pm 0.1 \mathrm{~B}$ & $2.6 \pm 0.2 \mathrm{bAB}$ & $2.5 \pm 0.0 \mathrm{bA}$ & $2.5 \pm 0.1 \mathrm{aAB}$ & $2.5 \pm 0.1 \mathrm{aAB}$ & 13.080 & 0.0109 \\
\hline & $\mathrm{H}^{2}$ & - & 75.996 & 60.286 & 6.163 & 39.711 & & \\
\hline & $P$ & - & 0.000 & 0.000 & 0.0459 & 0.018 & & \\
\hline
\end{tabular}

${ }^{1}$ Means followed by the same capital letter in the lines and lowercase letters in columns do not differ by ${ }^{2}$ Kruskal Wallis or ${ }^{3}$ Tukey tests $(\mathrm{p}<0.05)$. *Standard Error (SE).

Simple linear regression analysis revealed that the total number of spikelets (empty and filled) per panicle, the number of filled grains per panicle, and the average weight of filled grains per panicle of rice were inversely proportional to the percentage of defoliation, lower in higher percentages of defoliation and in the first stages of development of rice plants, mainly in V8 (Figs. 3ACE). The number of empty spikelets per panicle and percentage of damage are directly proportional to the increase in the percentages of defoliation, which was higher mainly in the vegetative stage (Figure 3B). The mass of 100 filled grains of rice was not correlated with the percentages of defoliation throughout the development of plants (Figure 3F).

The mass of 100 rice grains increased in plants with defoliation of $25 \%$ and $50 \%$ compared to that of the control group in V8 (Table 1). Some studies reported that in rice fields with higher density, the reduction in leaf area due to artificial defoliation or the attack by caterpillars may not result in a decrease in productivity, but rather often increase production (MARTINS et al., 1982). Since this was observed only in the V8 stage, this might be correlated with the ability of the plant to recover from defoliation early in the development, as observed for this stage.

These results demonstrate that grain mass is negatively affected when defoliation occurs mainly in the vegetative stage, although the decrease observed for grain mass after defoliation of $75 \%$ and $90 \%$ in stage R3/R4 was similar to those found in the vegetative stages examined (Figure 3E). Bertoncello et al. (2011) observed this same trend in mass reduction for the vegetative stage V11 for defoliations of $25 \%, 50 \%, 75 \%$, and $100 \%$. However mass reduction was much less pronounced than those found in the present study, under $22 \%$ in the highest percentage of defoliation. However these authors conducted the study under controlled conditions of temperature and humidity in a greenhouse, providing optimal conditions for the biological response to plant's development. Besides that, these results may be associated with the rice variety used, which may respond differently to the various percentages of defoliation.

Our results for rice grain mass are in agreement with the ones reported by Guindo et al. (1992) that described that the accumulation of nitrogen in leaves and their later distribution to the 
reproductive portions are relevant for the production of grains, since leaves are the main structure storing nitrogen (MAE, 1997). Ntanos and Koutroubas (2002) reported that the period of maximum $\mathrm{N}$ absorption (65\%) occurs 10 days after the formation of panicle in the stem. Thus, any decrease in leaf area during the vegetative phase of rice plants can directly interfere in the availability of $\mathrm{N}$, causing grain yield reduction. Isla (1975) observed pronounced reductions in rice production when defoliation occurred after the formation of the floral primordium (reproductive stage). Other authors have reported this same pattern for artificial defoliation in different cash crops (ENYI, 1975; KOOGAN, 1976).

Although similar studies with other varieties and types of rice (lowland or deep water, for example) are needed, our findings provide a framework for varieties used in different rice producing countries. For upland rice Cambará variety, when defoliation occurs in the vegetative stage, farmers should employ control measures to prevent crop loss. However, defoliation of up to $50 \%$ during the reproductive stage, did not affect the number of filled grains, total spikelets per panicle, and mass of filled grains per panicle. Leaf reduction can be monitored in the field and pest control performed only when needed. Consequently, monitoring reduces the expenses with pesticide applications. In addition, this information contributes to reduce the cases of accidents with workers from the excessive use of chemical products, since the control of defoliating insects is performed on a rational basis, which also decreases the quantities of chemical pollutants released into the environment.

\section{ACKNOWLEDGMENTS}

The authors acknowledge the farmers of the Fazenda Florentino, Marlete Florentino, Eurides Florentino (in memorian) and Nadir de Lima Florentino (in memoriam) for allowing this research on their property. We thank also the Conselho Nacional de Desenvolvimento Científico e Tecnológico $(\mathrm{CNPq})$ and the Coordenação de Aperfeiçoamento de Pessoal de Nível Superior (CAPES), for providing scholarships to the first author.

RESUMO: A simulação do ataque de insetos desfolhadores fornece uma medida do nível de dano que uma cultura pode suportar em um determinado estágio de desenvolvimento e também permite quantificar a perda de produtividade. Assim, este estudo avaliou os efeitos de níveis crescentes de desfolha artificial em plantas de arroz de terras altas em condições de campo, na produção de grãos em três estádios fenológicos: na fase vegetativa V8 (formação do colar na $8^{a}$ folha da haste principal), estágio vegetativo V12 (formação da folha bandeira) e fase reprodutiva R3/R4 (liberação da panícula ou antese). A porcentagem de dano em todos os estágios aumentou significativamente a partir de $25 \%$ de desfolha, e foi maior quando ocorreu nos estágios V8 e V12. Níveis de desfolhas de até $50 \%$ no estádio reprodutivo não influenciaram a quantidade de grãos cheios, número total de espiguetas por panícula e peso de grãos cheios por panícula, e portanto, o controle de pragas desfolhadoras não é necessário nesta fase. Os dados mostram que o controle de insetos mastigadores de folhas no arroz de terras altas deve ser restrito à fase vegetativa.

PALAVRAS-CHAVE: Manejo Integrado de Pragas. Redução de área foliar. Cultura de arroz.

\section{REFERENCES}

BARRIGOSSI, J. A. F. Technical recommendations for irrigated rice in Mato Grosso do Sul. Santo Antônio de Goiás: Embrapa Rice and Beans, (Documentos 255), 140p, 2010.

BERTONCELLO, T. F.; LIMA-JÚNIOR, I. S.; MELO, E. P.; FONSECA, P. R. B. DEGRANDE, P. E. Artificial defoliation simulating pest damage on rice under greenhouse conditions. Revista Acadêmica Ciências Agrárias e Ambientais, Curitiba, v. 9, p. 123-127, 2011.

BOWLING, C. C. Simulated insect damage to rice: effects of leaf removal. Journal of Economic Entomology, Annapolis, v. 71, p. 377-378, 1978. https://doi.org/10.1093/jee/71.2.377

BUENO, A. F.; PANIZZI, A. R.; CORRÊA-FERREIRA, B. S.; HOFFMANN-CAMPO, C. B.; SOSAGOMEZ, D. R.; GAZZONI, D. L.; HIROSE, E.; MOSCARDI, F.; CORSO, I. C.; OLIVEIRA, L. J.; ROGGIA, 
S. Histórico e evolução do manejo integrado de pragas da soja no Brasil. In: HOFFMANN-CAMPO, C.B.; CORREAA-FERREIRA, B. S.; MOSCARDI, F. (Eds.), Soja: Manejo Integrado de Insetos e outros Artrópodes-Praga. 1. ed. Embrapa, Brasília, p. 37-74, 2012.

CHANG, T. Origin, domestication, and diversification. In: SMITH, C. W.; DILDAY, R. H. (Ed.). Rice: Origin, history, technology, and production. New Jersey: John Wiley \& Sons, 2003. p. 3-26.

COATS, B. Global Rice Production. In: SMITH, C. W.; DILDAY, R. H. (Ed.). Rice: Origin, history, technology, and production. New Jersey: John Wiley \& Sons, 2003. p. 247-270.

COSTA, E. C.; GUEDES, J. V. C.; FRANÇA, J. A. S.; FARIAS, J. R. Efficiency of "neonicotinoid” for controlling Oryzophagus oryzae (Coleoptera: Curculionidae) larvae in irrigated rice through seed treatment. Revista da FZVA, Uruguaiana, v. 13, p. 123-131, 2006.

COSTA, E. C.; LINK, D. Effect of insecticides on predators at paddy rice fields. Revista da FZVA, Uruguaiana, v. 6, p. 24-31, 1999.

COUNCE, P. A.; T. C. KEISLING, MITCHELL, A. J. A uniform, objective, and adaptive system for expressing rice development. Crop Science, Madison, v. 40, p. 436-443, 2000.

https://doi.org/10.2135/cropsci2000.402436x

DIDONET, J.; DIDONET, A. P. P.; ERASMO, E. L.; SANTOS, G. R. Population dinamic of pest and their natural enemies in upland rice, at the Gurupi-TO. Bioscience Journal, Uberlândia, v. 17, p. 67-76, 2001.

ENYI, B. A. C. Effects of defoliation on growth and yield in groundnut (Arachis hypogea), cowpeas (Vigna unguiculata), soybeans (Glycine max) and green gram (Vigna aurens). Annals of Applied Biology, Malden, v. 79, p. 55-66, 1975. https://doi.org/10.1111/j.1744-7348.1975.tb01522.x

FAO - Food and Agriculture Organization of the United Nations. Statistics Division (ESS). Available at: $<$ http://faostat.fao.org/beta/en/\#data>. Accessed 28 October 2016.

FAZOLIN, M.; ESTRELA J. L. V. Effect of different levels of defoliation on productivity of common beans (Phaseolus vulgaris L. cv. Perola). Ciência e Agrotecnologia, Lavras, v. 27, p. 978-984, 2003.

FERREIRA, C. M.; SANTIAGO, C. M. Informações técnicas sobre o arroz de terras altas: estados de Mato Grosso e Rondônia - safras 2010/2011 e 2011/2012. Santo Antônio de Goiás: Embrapa Rice and Beans, (Documentos 268). 112 p, 2012.

GOMES, A. S.; MAGALHÃES-JÚNIOR, A. M. Arroz irrigado no Sul do Brasil. Pelotas: Embrapa Clima Temperado, 2004. 899p (Informação Tecnológica), 2004.

GRÜTZMACHER, A. D.; NAKANO, O.; MARTINS, J. F. S.; GRÜTZMACHER, D. D.; LOECK, A. E. Efeito do desfolhamento artificial sobre a produção e ciclo do arroz irrigado Embrapa 6-chuí. Current Agricultural Science and Technology, Pelotas, v. 5, p. 68-74, 1999a. https://doi.org/10.1590/S030180591999000300019

GRÜTZMACHER, A. D.; NAKANO, O.; MARTINS, J. F. S.; GRÜTZMACHER, D. D.; LOECK, A. E. Foliage consumption by Spodoptera frugiperda (J.E. Smith) (Lepidoptera: Noctuidae) on irrigated rice cultivars. Anais da Sociedade Entomológica do Brasil, Londrina, v. 28, p. 519-525, 1999b.

GUINDO, D.; WELLS, B. R.; WILSON, C. E.; NORMAN, R. J. Seasonal accumulation and partitioning of N15 in rice. Soil Science Society of America Journal, Madison, v. 56, p. 1521-1527, 1992. 
HOFFMANN-CAMPO, C. B.; MOSCARDI, F.; CORREAA-FERREIRA, B. S.; OLIVEIRA, L. J.; SOSAGOMEZ, D. R.; PANIZZI, A. R.; CORSO, I. C.; GAZZONI, D. L. Pragas da soja no Brasil e seu manejo integrado. Londrina, Embrapa Soja, 70p. (Embrapa Soja. Circular Técnica 30), 2000.

ISLA, L. H. Determinación del período crítico de daños foliares en el cultivo del arroz. Centro Agricola, Santa Clara, v. 2, p. 67-76, 1975.

KOOGAN, M. Evaluation of injury levels for soybean insect pests. In: HILL L.D. (Ed.) World soybean research. Danville, Interstate, pp. 513-533, 1976.

KRINSKI, D. First report of Squash Vine Borer, Melittia cucurbitae (Harris, 1828) (Lepidoptera, Sessidae) in Brazil and South America: distribution extension and geographic distribution map. Check List, São Paulo, v. 11, n. 1625, p. 1-3, 2015. https://doi.org/10.15560/11.3.1625

KRINSKI, D.; GODOY, A. F. First record of Helicoverpa armigera (Lepidoptera, Noctuidae) feeding on Plectranthus neochilus (Lamiaceae) in Brazil. Florida Entomologist, Lutz, v. 98, n. 4, p. 1243-1245, 2015.

LOECK, A. E.; GRÜTZMACHER, A.; NAKANO, O.; MARTINS, J.; GRÜTZMACHER, D. Efeito do desfolhamento artificial sobre a produção e ciclo do arroz irrigado Embrapa 6-chuí. Current Agricultural Science and Technology, Pelotas, v. 5, p. 68-74, 1999.

MACHADO, R. C. M.; GARCIA, F. R. M. Levantamento de pragas e inimigos naturais ocorrentes em lavoura de arroz no município de Cachoeirinha, Rio Grande do Sul. Revista de Ciências Ambientais, Canoas, v. 4, p. 57-68, 2010.

MAE, T. Physiological nitrogen efficiency in rice: Nitrogen utilization, photosynthesis, and yield potential. Plant and Soil, Crawley, v. 196, p. 201-210, 1997. https://doi.org/10.1023/A:1004293706242

MARTINS, J. F. S, CARBONARI, J. J. VENDRAMIM, J. D. Larval damage simulation of Oryzophagus oryzae (Coleoptera: Curculionidae) on irrigated rice cultivars. Ciência Rural, Santa Maria, v. 34, p. 653-659, 2004a. https://doi.org/10.1590/S0103-84782004000300001

MARTINS, J. F. S.; BARRIGOSSI, J. A. B.; OLIVEIRA, J. V. CUNHA, U. S. Situação do manejo integrado de insetos-praga na cultura do arroz no Brasil. Pelotas: Embrapa Clima Temperado, 40p. (Documentos, 290), 2009.

MARTINS, J. F. S.; FERREIRA, E. PINHEIRO, B. S. Simulated damage to upland rice by leaf caterpillar. Pesquisa Agropecuária Brasileira, Brasília, v. 17, p. 1113-1119, 1982.

MARTINS, J. F. S.; GRÜTZMACHER, A. D. CUNHA, U. S. Descrição e manejo integrado de insetospraga em arroz irrigado. In: GOMES A. S.; MAGALHÃES-JUNIOR, A. M. (Eds.). Arroz irrigado no Sul do Brasil. Brasília: Embrapa informação tecnológica. pp. 635-676, 2004b.

MARTINS, J. P. S.; AFONSO, A. P. S. Importância econômica de Spodoptera Frugiperda (J.E. Smith) (Lepidoptera: Noctuidae) como praga do arroz no Brasil. Pelotas: Embrapa Clima Temperado, 31p. (Documentos, 213), 2007.

MOSCARDI, F. VILLAS-BÔAS, G. L. Influência da desfolha artificial, em quatro diferentes estádios fenológicos da planta, sobre o rendimento e outras características do girassol. Resultados de pesquisa do girassol. In: Reunião Nacional de Pesquisa de Girassol, 2.; Londrina, PR, p. 25-27, 1982.

NTANOS, D. A.; KOUTROUBAS, S.D. Dry matter and N accumulation and translocation for Indica and Japonica rice under Mediterranean conditions. Field Crops Research, Amsterdam, v. 74, p. 93-101, 2002. https://doi.org/10.1016/S0378-4290(01)00203-9 
PATHAK, M. D.; KHAN, Z. R. Insect Pests of Rice. International Rice Research Institute, International Centre of Insect Physiology and Ecology, Philippines, 89p, 1994.

SHAD, S. A.; SAYYED, A. H.; FAZAL, S.; SALEEM, M. A.; ZAKA, S. M.; ALI, M. Field evolved resistance to carbamates, organophosphates, pyrethroids, and new chemistry insecticides in Spodoptera litura Fab. (Lepidoptera: Noctuidae). Journal of Pest Science, Heidelberg, v. 85, p. 153-162, 2012. https://doi.org/10.1007/s10340-011-0404-z

SILVA, F. A. S.; AZEVEDO, C. A. V. Versão do programa computacional Assistat para o sistema operacional Windows. Revista Brasileira de Produtos Agroindustriais, Campina Grande, v.4, n.1, p71-78, 2002. https://doi.org/10.15871/1517-8595/rbpa.v4n1p71-78

SILVA, P. H. S. Avaliação de danos de Spodoptera frugiperda (J.E. Smith, 1797) (Lepidoptera-Noctuidae) em cultura de arroz (Oryza sativa L.) em condições hídricas variáveis. 76p. Dissertation (Master Degree) Pósgraduação em Entomologia, Universidade de São Paulo (Escola Superior de Agricultura "Luiz de Queiroz"), 1984.

WALTER, L. C.; ROSA, H. T.; STRECK, N. A.; FERRAZ, S. E. Y. Adaption and evaluation of the infocrop model for simulating grain yield of irrigated rice. Engenharia Agrícola, Jaboticabal, v. 32, p. 510-521, 2012.

WATSON, D. J. The physiological basis of variation in yield. Advances in Agronomy, v. 4, p. 101-145, 1952. https://doi.org/10.1016/S0065-2113(08)60307-7

YUAN, X. H.; SONG, L. W.; ZHANG, J. J.; ZANG, L. S.; ZHU, L.; RUAN, C. C.; SUN, G. Z. Performance of four Chinese Trichogramma species as biocontrol agents of the rice striped stem borer, Chilo suppressalis, under various temperature and humidity regimes. Journal of Pest Science, Heidelberg, v. 85, p. 497-504, 2012. https://doi.org/10.1007/s10340-012-0456-8 